\title{
Multi-Decadal Changes in Tundra Environments and Ecosystems: Synthesis of the International Polar Year-Back to the Future Project (IPY-BTF)
}

\author{
Terry V. Callaghan, Craig E. Tweedie, Jonas Åkerman, Christopher Andrews, Johan Bergstedt, \\ Malcolm G. Butler, Torben R. Christensen, Dorothy Cooley, Ulrika Dahlberg, Ryan K. Danby, \\ Fred J. A. Daniëls, Johannes G. de Molenaar, Jan Dick, Christian Ebbe Mortensen, Diane Ebert-May, \\ Urban Emanuelsson, Håkan Eriksson, Henrik Hedenås, Greg. H. R. Henry, David S. Hik, John E. Hobbie, \\ Elin J. Jantze, Cornelia Jaspers, Cecilia Johansson, Margareta Johansson, David R. Johnson, \\ Jill F. Johnstone, Christer Jonasson, Catherine Kennedy, Alice J. Kenney, Frida Keuper, Saewan Koh, \\ Charles J. Krebs, Hugues Lantuit, Mark J. Lara, David Lin, Vanessa L. Lougheed, Jesper Madsen, \\ Nadya Matveyeva, Daniel C. McEwen, Isla H. Myers-Smith, Yuriy K. Narozhniy, Håkan Olsson, \\ Veijo A. Pohjola, Larry W. Price, Frank Rigét, Sara Rundqvist, Anneli Sandström, Mikkel Tamstorf, \\ Rik Van Bogaert, Sandra Villarreal, Patrick J. Webber, Valeriy A. Zemtsov
}

\begin{abstract}
Understanding the responses of tundra systems to global change has global implications. Most tundra regions lack sustained environmental monitoring and one of the only ways to document multi-decadal change is to resample historic research sites. The International Polar Year (IPY) provided a unique opportunity for such research through the Back to the Future (BTF) project (IPY project \#512). This article synthesizes the results from 13 papers within this Ambio Special Issue. Abiotic changes include glacial recession in the Altai Mountains, Russia; increased snow depth and hardness, permafrost warming, and increased growing season length in sub-arctic Sweden; drying of ponds in Greenland; increased nutrient availability in Alaskan tundra ponds, and warming at most locations studied. Biotic changes ranged from relatively minor plant community change at two sites in Greenland to moderate change in the Yukon, and to dramatic increases in shrub and tree density on Herschel Island, and in subarctic Sweden. The population of geese tripled at one site in northeast Greenland where biomass in non-grazed plots doubled. A model parameterized using results from a BTF study forecasts substantial declines in all snowbeds and increases in shrub tundra on Niwot Ridge, Colorado over the next century. In general, results support and provide
\end{abstract}

Electronic supplementary material The online version of this article (doi:10.1007/s13280-011-0179-8) contains supplementary material, which is available to authorized users. improved capacities for validating experimental manipulation, remote sensing, and modeling studies.

Keywords IPY · Glaciers · Permafrost . Snow stratigraphy $\cdot$ Tundra vegetation . Limnology $\cdot$ Shrubs $\cdot$ Treeline

\section{INTRODUCTION}

Climate change over the past half century has been both dramatic and amplified in the Arctic (Callaghan et al. 2005; IPCC 2007; Kaufman et al. 2009). Polar and alpine environments appear to be changing rapidly due to increases in temperature, as well as other factors such as altered hydrology (Smith et al. 2005), and land use (Kumpula et al. 2011). The impacts on ecosystems and their function have potential consequences for local residents (Chapin et al. 2005a) and the global community (Chapin et al. 2005b; Walter et al. 2007; Schuur et al. 2008). Tundra areas are vast and diverse, however, and the knowledge of geographical variation in environmental and ecosystem changes is limited to relatively few locations such as flagship observatories (Shaver et al. 2004; NRC 2006), or to remote sensing approaches that integrate a variety of different ecosystem properties to single indices (Stow et al. 2004), and is limited to mostly just the past few decades (e.g., Bhatt et al. 2010). Given the implications of change, the 
paucity of observations in tundra ecosystems (Callaghan et al. 2005) relative to other regions on the globe, and the dramatic and rapid nature of observed changes in some locations (e.g., ACIA 2005; Hinzman et al. 2005; Johansson et al. 2006; Post et al. 2009; Bhatt et al. 2010; Forbes et al. 2010), there is an urgent need to further assess the type and extent of current and future change in tundra regions. The International Polar Year (IPY) provided a context, stimulus and timely opportunity for rescuing and re-visiting old research sites and data sets to collate data on past changes, to pass knowledge from old to new generations of researchers, and to document the dynamics of change to facilitate detection and attribution of future changes. Consequently, the project "Retrospective and Prospective Vegetation Change in the Polar Regions: Back to the Future (BTF)" was proposed and endorsed as an IPY activity (IPY project \#512). The aims of the BTF Project were (Callaghan et al. 2011a [this issue]):

1. To assess multi-decadal past changes in the structure and function of polar terrestrial and freshwater ecosystems and environments in relation to diverse drivers of change

2. To assess the current status of polar ecosystems and their biodiversity

3. To permanently record precise locations of old sites in order to perpetuate platforms for (a) the assessment of future changes in polar ecosystems and their environments and (b) sampling for polar research and assessment programmes.

With national funding support, teams of researchers revisited former sites and data sets throughout the Arctic and several alpine regions. These efforts have amounted to a gamut of "BTF" studies that are collectively geographically expansive and disciplinarily diverse. A selection of these studies are introduced and presented in the current Special Issue (Callaghan and Tweedie 2011 [this issue]). In this paper, we focus on aim 1 (see above), to present and discuss the geographic and disciplinary variability in environmental and ecosystem changes observed at widely distributed locations in the Arctic and at two alpine locations. Because change, or lack of change, is estimated from site re-visits or retrieval of data, the essence of aim 2 above ("To assess the current status of polar [and alpine environments and] ecosystems and their biodiversity") is implicit throughout. The site re-visits and retrieval of old data have ensured that old study locations have been recorded with modern global positioning systems (GPS) and that data sets are stored (within papers, as on-line material in this Special Issue, or in national data repositories), thereby fulfilling aim 3 above.

Within the time frame of the fourth IPY (2007-2009), the BTF study could not be comprehensive in time or space. Instead, snapshots in time are presented in cases where continuous data sets are missing, and the geographical coverage can be viewed as case studies that could be used for establishing baselines for future change detection, hypotheses of future change, and/or directing future monitoring effort. In areas without extensive and sustained long term monitoring, BTF studies represent one of the only options by which change over multi-decadal time scales can be attained for many tundra regions. This Special Issue begins to collate information from BTF studies and presents 13 papers that assess multi-decadal change and variability in the biophysical environment of northern tundra ecosystems. This synthesis pays particular attention to vegetation, focusing particularly on productivity trends and changes in plant species richness and community structure. Because some plant communities have not changed substantially, yet show early signs of change, we also discuss communities in transition and refer to a study that models community change based on probabilities of transitions between communities. Figure 1 highlights the broad geographic coverage and disciplinary breadth of BTF studies as well as key findings from published papers, papers from this Special Issue, and others that are in preparation. Following conclusions from the study, we outline the legacy from BTF, which was a prerequisite of IPY endorsed projects (Krupnik et al. 2011).

\section{MULTI-DECADAL VARIATION IN THE ABIOTIC ENVIRONMENT}

Case studies from the Altai Mountains of southern Siberia and the Swedish sub-Arctic show considerable changes in the cryosphere (glaciers, snow, and lake ice) over the past 3 to 6 decades. These findings are in line with a pan-Arctic assessment of the changing cryosphere (SWIPA 2011). Long-term observations from the Altai Mountains, where about 1,030 glaciers with a total area of $805 \mathrm{~km}^{2}$ and volume of $42.5 \mathrm{~km}^{3}$ were recorded prior to 1978 , have been up-dated and made available in this volume. Between 1952 and 2008, glacier area decreased by $9-27 \%$, and volume by $12-24 \%$. As a result of glacier degradation, the total number of glaciers decreased to 953 with an area of $724 \mathrm{~km}^{2}$ and volume of $38 \mathrm{~km}^{3}$ (Narozhniy and Zemtsov 2011 [this issue]). During this period, the average summer air temperature increased by between about 0.2 to $1.1^{\circ} \mathrm{C}$ and annual precipitation increased by $8-10 \%$.

In the Swedish sub-Arctic, snow depth measurements at one location showed a gradual increase over the twentieth century (Kohler et al. 2006) but an accelerating decrease since the mid 1980s (Callaghan et al. 2010). In the present Special Issue, analysis of repeat photography spanning 30 years (1978-2007) by Andrews et al. (2011, this issue) 
has extended snow measurements from one location to the landscape level in a mountain area. Low and high elevation snow cover were reduced by 5.1 and 3.1 weeks, respectively, and there was a general rate of decline at high elevations of 0.1 week year $^{-1}$ between 1978 and 2007. At lower altitudes, the on-set date of snow cover was found to be more or less stable for the period, whereas the spring snow thaw was found to be occurring significantly earlier at a rate of 0.12 week year $^{-1}$ (Andrews et al. 2011 [this issue]). Over the period 1978-2008, simple linear regression analysis showed that annual mean temperatures increased by $2.06^{\circ} \mathrm{C}$ at a rate of $0.07 \quad(\mathrm{SE}=0.01)$ ${ }^{\circ} \mathrm{C}$ year $^{-1}$. Also in the Swedish sub-Arctic, C. Johansson et al. (2011 [this issue]) document changes in snow properties such as grain size throughout the vertical snow profile that indicate weather conditions during the winter such as extreme warming events and brief snow melt. This unique record of snow stratigraphy over a 50 year period (1961-2009) also shows a significant increase in very hard snow layers with harder snow in early winter and more moist snow in spring. These changes are coupled with a striking increase in very hard snow layers at the ground level between 1961 and 2009-probably in response to more warming events in winter rather than general increases in winter temperatures (C. Johansson et al. 2011 [this issue]). These hard snow layers have major implications for plants (Bokhorst et al. 2009) and animals (e.g., Kausrud et al. 2008).

Monitoring of permafrost has been ongoing since 1978 in the Abisko area, northernmost Sweden. Measurements of active layer depth at nine lowland mires showed increased active layer thickness at all sites and disappearance of permafrost at three sites (Åkerman and Johansson 2008). In 1980, boreholes were drilled in three mires to record permafrost temperatures. During the IPY "Back to the Future" and "Thermal State of Permafrost" projects, new boreholes were drilled that enabled year-round temperature monitoring (M. Johansson et al. 2011 [this issue]). Mean annual ground temperatures in the mires are now close to $0^{\circ} \mathrm{C}$, ranging from -0.16 to $-0.47^{\circ} \mathrm{C}$ at $5 \mathrm{~m}$ depth. Ground temperature in the upper and lower permafrost profiles increased 0.4 to $1^{\circ} \mathrm{C}$ between 1980 and 2002. At one of the mires, permafrost thickness decreased from $15 \mathrm{~m}$ in 1980 to ca. $9 \mathrm{~m}$ in 2009, with an accelerating thawing trend during the last decade.

Lake ice covering the large Torneträsk in the Swedish sub-Arctic has decreased in duration by a substantial 40 days over the 20 th and 21 st centuries with accelerating losses since the mid 1980s (Callaghan et al. 2010). Within the "Back to the Future" project, the long-term manual observations have been augmented by analysis of repeat photography over the period 1978-2008 (see Andrews et al. 2011 [this issue]). Between 1978 and 2007, the winter freeze of Lake Torneträsk was found to be occurring significantly later in the year by 0.20 week year ${ }^{-1}$. Regression estimates show lake freeze-up to be occurring 5.8 weeks later by the end of this period, during week 2 (15-22 January) in 2007, compared with week 48 (26 November-02 December) in 1978. The on-set of lakefreeze and the average temperatures in November and December were found to be significantly correlated. These correlations suggest that lake freeze could be delayed by 0.55 weeks and 0.49 weeks for every $1^{\circ} \mathrm{C}$ increase in November and December average temperatures, respectively. April, May, and June temperatures were all found to be significantly correlated with the first date of 'ice free' water, suggesting earlier melts of $0.46,0.49$, and 0.61 weeks for every $1^{\circ} \mathrm{C}$ rise in respective average temperature.

Assessments of climate change impacts in the Arctic emphasize the importance of hydrological changes for ecology, biogeochemical cycling, land use, and water resources (e.g., ACIA 2005; Hinzman et al. 2005; IPCC 2007; SWIPA 2011). However, changes in soil moisture throughout the Arctic are variable, with some areas experiencing the drying of ponds and/or loss of standing surface water in Alaska (Hinzman et al. 2005), Siberia (Smith et al. 2005), and Canada (Smol and Douglas 2007; Bhatt et al. 2010) and others experiencing water logging and pond formation such as in sub-Arctic Sweden (Johansson et al. 2006). Within the BTF Project, photographic evidence resulting from site re-visits has also shown drying of a pond in Central mid-West Greenland between 1970 and 2009 (Callaghan et al. 2011b [this issue]). Repeated sampling and vegetation mapping of a shallow pond in Southeast Greenland has shown a similar trend over approximately the past 100 years with conspicuous vegetation changes (Daniëls and de Molenaar 2011 [this issue]). These changes suggest increased evaporation/precipitation ratios associated with environmental warming and possibly decreasing snow accumulation in winter (Daniëls and de Molenaar 2011 [this issue]). In Alaska, re-visits to International Biological Programme (1970s) study sites near Barrow were made by Lougheed et al. (2011 [this issue]). The Barrow IBP tundra ponds represent one of the very few locations in the Arctic where changes in freshwater ecosystem structure and function have been documented over a period of four decades. The BTF project at Barrow showed significant changes in the physical, chemical and biological characteristics of these ponds over time due to the rapid climate changes that have occurred in northern Alaska. These changes include increased water temperatures, increased water column nutrient concentrations, the presence of at least one new chironomid species, and increased macrophyte cover. However, significant annual variation in many measured variables was observed and 

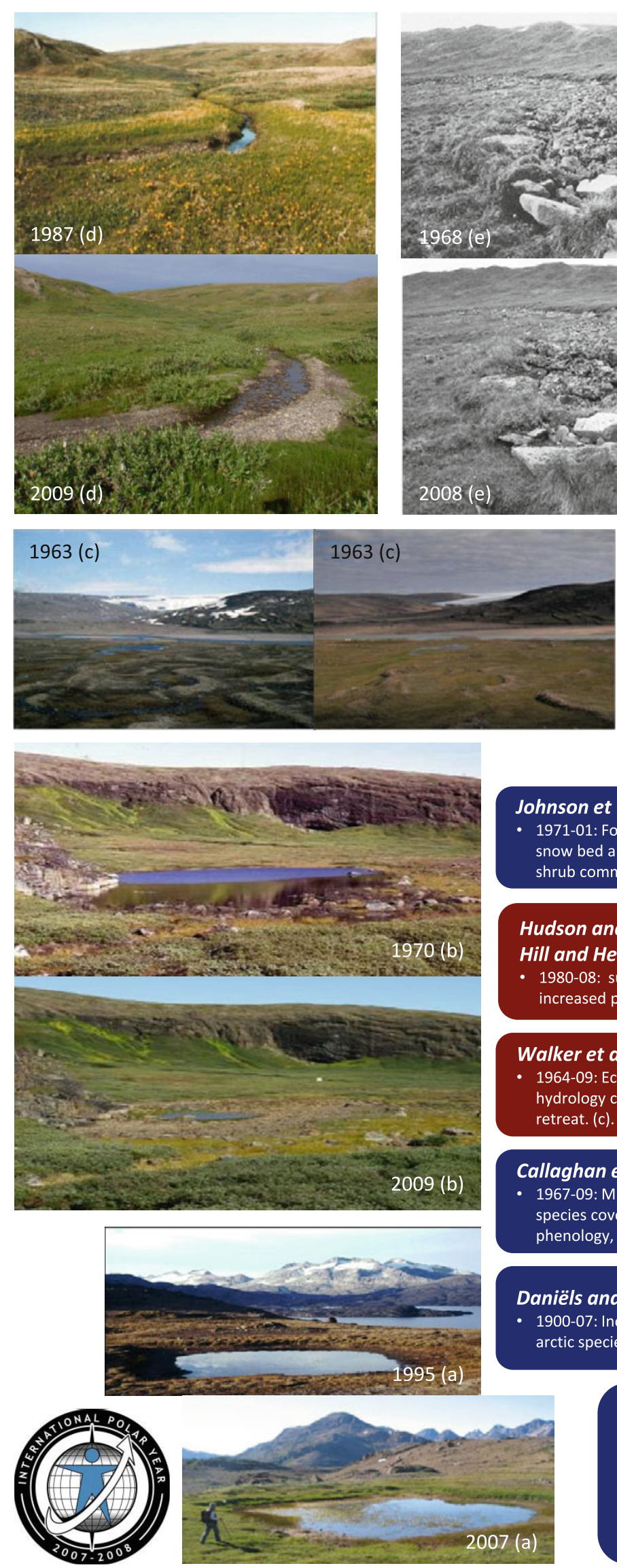

\section{Johnson et al.}

1971-01: Forecast loss of snow bed and increase in shrub communities.

Hudson and Henry 2009, Hill and Henry 2011

- 1980-08: summer warming, increased plant biomass.

\section{Walker et al. 2010}

- 1964-09: Ecosystem and surface hydrology change, glacial retreat. (c).

\section{Callaghan et al.}

- 1967-09: Minor change in species cover, earlier phenology, drying of pond. (b).

\section{Daniëls and de Molenaar}

1900-07: Increased cover of low

arctic species, drying of pond. (a).

Madsen et al.

- 1982-08: June-July temperature increased, ungrazed biomass doubled, geese population tripled.

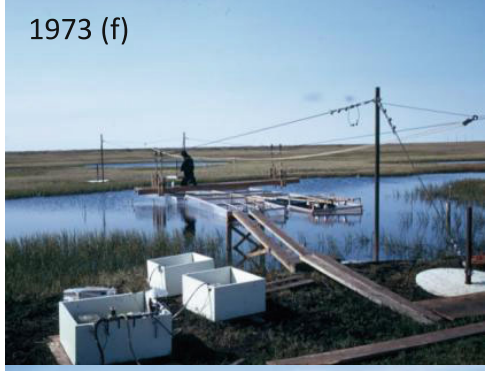

2010 (f)

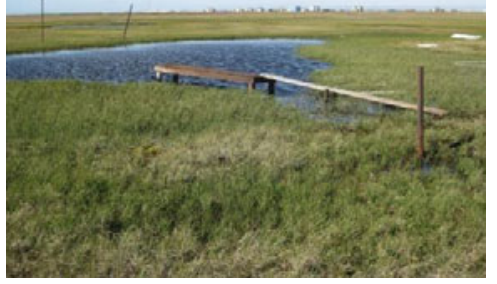

al.

68-10: Increased

munity change

Myers-Smith et al.

09-09: Increased shrub cover and height. (d).
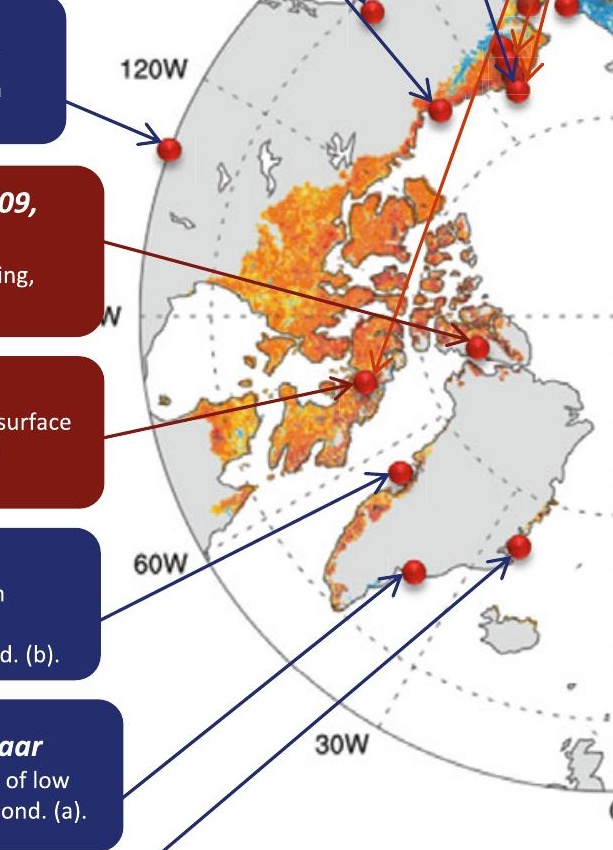

1970-10: Increased

pond temperatures and nutrient concentrations. (f).
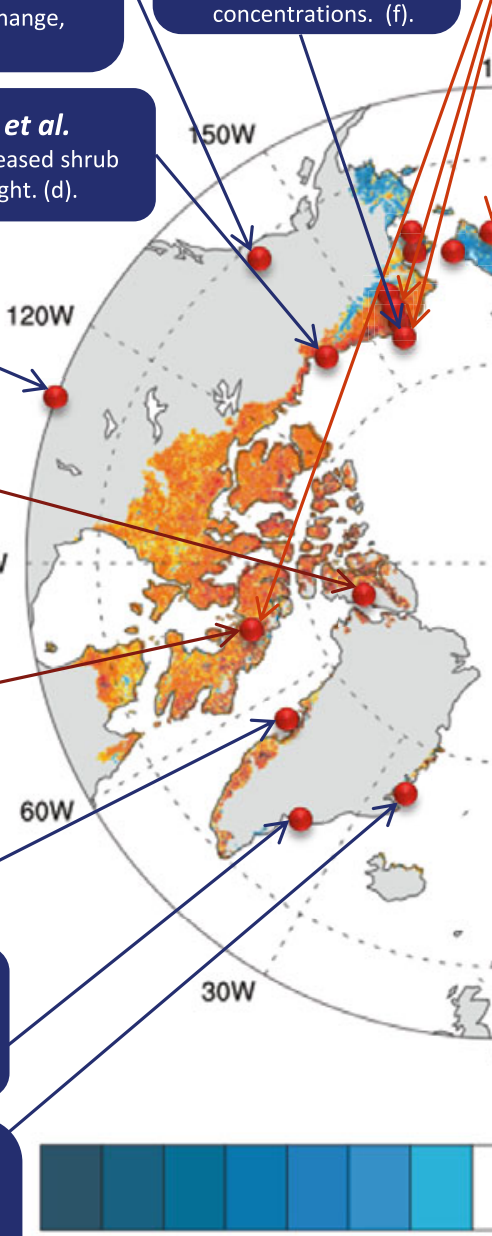

$\begin{array}{lllllll}-25 & -20 & -15 & -10 & -5 & -2 & -1\end{array}$

Bhatt et al. 2010 (percent chang 


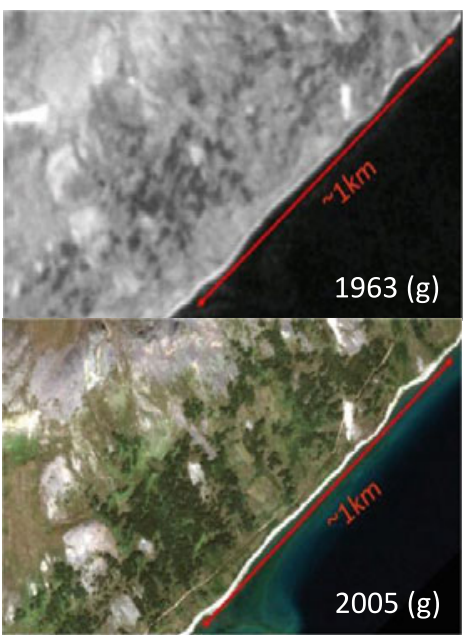

Lara et al.

- 1964-10: Change in ecosystem function.

Villarreal et al.

- 1964-10: Plant community change. (h).

Lin et al. (multiple sites)
-1948-08: Land cover change in
Beringia. (g).
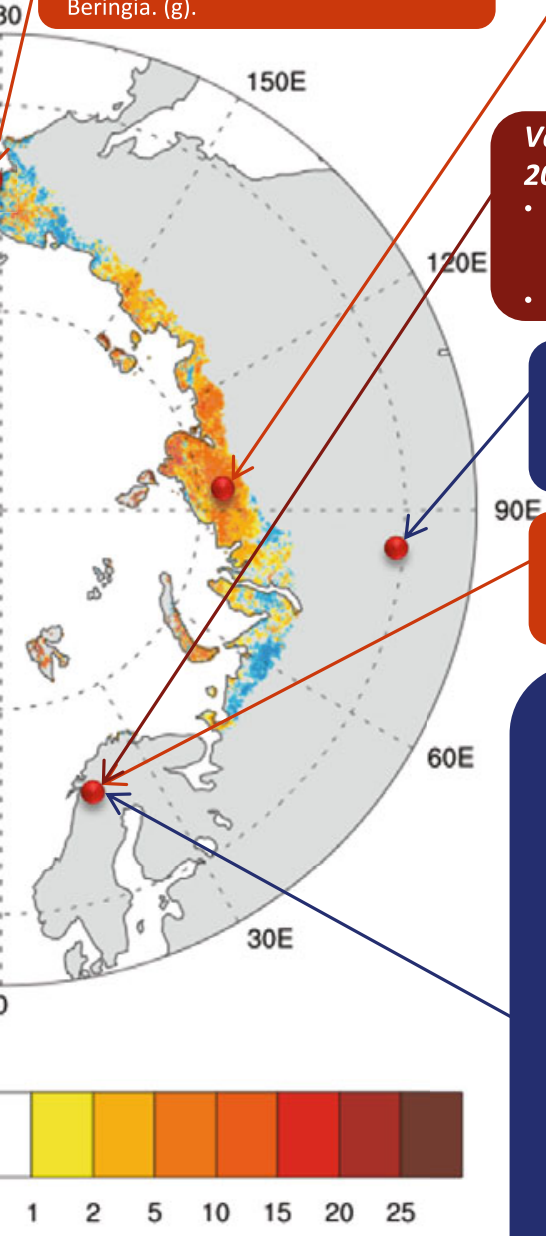

\section{- Maximum NDVI}

e, 1982-2008)
Fig. 1 Environmental and ecosystem change in tundra regions: the International Polar Year Back to the Future Project. Blue box this issue, red box published studies, orange box in preparation studies. See text for details. The map shows changes in NDVI between 1982 and 2008. This map and figure c have been reproduced from Bhatt et al. (2010)

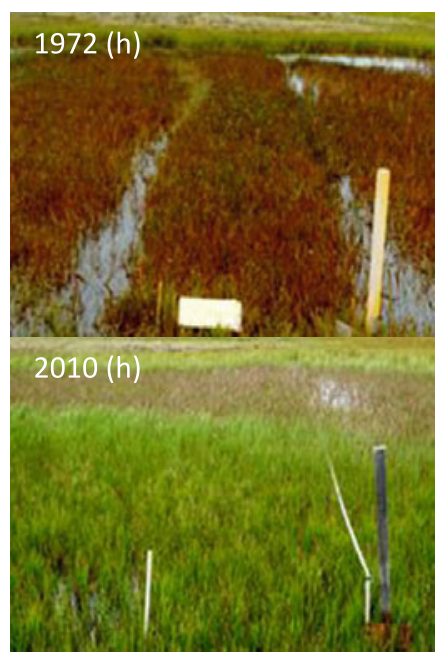

Matveyeva.

-1970-10: Minor vegetation change despite large change in landscape topography.

Van Bogaert et al. 2010, 2011

- 1912-09: Treeline locally advanced, descended or remained static. (j).

Aspen invasion at treeline.

\section{Narozhniy and Zemtsov}

- 1952-08: Warming, increased precipitation, decreased glacial extent and volume. (i).

\section{Hedenås et al.}

- 1980's-09: Minor change in meadow species composition.

\section{Andrews et al.}

- 1978-07: Warming, earlier lake and snow melt and budburst, decreased winter snow and ice cover.

Hedenås et al.

- 1997-10: Increased tree biomass, decreased snow bed vegetation cover.

C. Johansson et al.

- 1961-09: Increased snow hardness.

M. Johansson et al.

- 1978-09: Increased permafrost temperature, decreased permafrost thickness.

\section{Rundqvist et al.}

- 1976-10: Increased shrub and tree cover. (k).
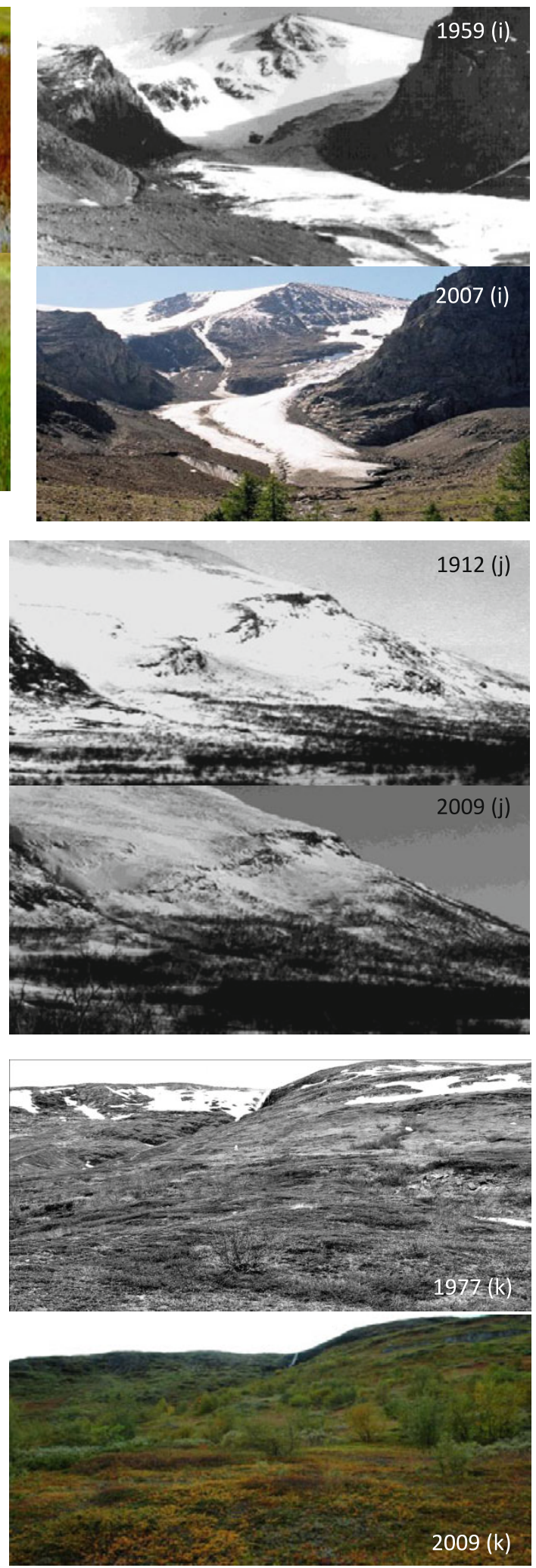
this variation must be taken into account when attempting to make statements about long-term change.

\section{MULTI-DECADAL VARIATION IN ARCTIC VEGETATION}

\section{Landscape, Plant Community, and Productivity Change}

Changes in plant communities specifically related to climate change date back to at least the late 1950s when shrub expansion was observed at the treeline in sub-arctic Sweden (Sandberg 1963), even though there was no apparent warming during that period (Callaghan et al. 2010). In the 1990s, many studies were published and showed that in response to climate warming, plant species range margins would extend upwards and northwards, plant productivity would increase, and species and life forms within communities would not respond equally, thereby leading to the formation of non-analogous plant communities. Most of these conclusions were based on experimental increases of air temperature in the field such as those conducted as part of the International Tundra Experiment (ITEX: Henry and Molau 1997; Arft et al. 1999; Walker et al. 2006) and several pre-ITEX warming experiments (Havström et al. 1993; Parsons et al. 1994; Chapin et al. 1995).

Recently, Bhatt et al. (2010) documented increased summer warmth and greening in arctic landscapes. They used a recently derived satellite data set spanning 1982-2008 and the normalized difference vegetation index, which is known to be a proxy of plant productivity in arctic landscapes (Boelman et al. 2003, 2005). Greening occurred over the majority of the circumarctic, in contrast to the browning of some boreal forests (Verbyla 2008), but was greatest along the northern coast of Alaska adjacent to the Beaufort Sea and in the Canadian High Arctic (Bhatt et al. 2010). Although there are limited time series observations from ground based studies that can be used to verify such observations of low spatial resolution satellite imagery, observations from several BTF-like studies that documented increased productivity (Hudson and Henry 2009) and vegetation succession following glacial retreat and loss of snowbeds (Webber et al., unpublished-see Walker et al. 2010) appeared to support the observed greening in northern Canada. The Bhatt et al. (2010) study, clearly demonstrates the extent and likely magnitude of change that has occurred in arctic landscapes over the past three decades but challenges the ecological community to define the changes in land cover and plant community composition and structure that are associated with these satellitederived changes.
Over the past decade, increasing evidence from ground observations and remote sensing has validated many of the generalized projections interpolated from manipulative experiments, but a complexity of responses from plant species and communities to climate warming has become apparent. Among the most dramatic changes reported is the general expansion and densification of shrubs and trees (Sturm et al. 2001; Tømmervik et al. 2004; Tape et al. 2006; Forbes et al. 2010; Hallinger et al. 2010; Van Bogaert et al. 2010; 2011) and mostly up-ward movement of the treeline (e.g., Kullman 2002; Danby and Hik 2007). In the Swedish sub-Arctic, however, treeline has increased in elevation, remained stable or descended down-slope within the past 50 to 100 years (Van Bogaert et al. 2011). This local complexity of biological change, which occurred under the same climate change regime, implies that a variety of drivers, perhaps interacting, are affecting tundra species and communities. With this context, the BTF vegetation projects provide a multi-decadal time scale perspective of change from widespread geographical locations, and from the landscape-scale rather than the research plot scale at which most manipulative experiments are conducted. Collectively, these studies also provide new capacities for ground validation of remote sensing products such as that of Bhatt et al. (2010) and also perspectives for the parameterization and verification of predictive models (sensu Wolf et al. 2008; Euskirchen et al. 2009; Wramneby et al. 2010). The BTF vegetation studies within this Special Issue present evidence of change from dramatic increases in treeline tree and shrub abundance in sub, mid and high arctic regions to subtle changes in species composition of plant communities.

In the sub-Arctic $\left(68^{\circ} \mathrm{N}\right)$, at forest line and treeline, Rundqvist et al. (2011 [this issue]) recorded the change in coverage of willow species, juniper, aspen, mountain birch, dwarf birch, and rowan over a 32-34-year period (1976/1977-2009/2010). There was a substantial increase of shrubs and tree cover (up to 600\%), particularly for dwarf birch and mountain birch and newly established aspen was recorded nearby by Van Bogaert et al. (2010). Other species revealed inconsistent changes among the plots. A re-survey in 2010 of biomass and plant community cover in 549 plots originally surveyed in 1997 in the same but wider area confirmed the results of Rundqvist et al.'s (2011) long-term study (Hedenås et al. 2011 [this issue]). In the latter study, Hedenås et al. recorded a $19 \%$ increase in tree biomass mainly within the existing birch forest and significant increases in the cover of two vegetation types"birch forest -heath with mosses" and "meadow with low herbs" (Hedenås et al. 2011 [this issue]). In contrast, the cover of snow bed vegetation had decreased significantly, which agrees with nearby observations made by Björk and Molau (2007), and results from resampling of 
marked vegetation plots in alpine tundra on Niwot Ridge, Colorado that spanned three decades (Johnson et al. 2011 [this issue]). The vegetation changes observed in northern Sweden might be caused by climate (Callaghan et al. 2010), as growing season length increased by 2.4 weeks from an estimated growing season of 12.1 weeks in 1978 to 14.6 weeks in 2007 (Andrews et al. 2011 [this issue]). Herbivory (Olofsson et al. 2009) and past human impact (Van Bogaert et al. 2009) may also partly explain these trends. Irrespective of the cause/s, the longer and shorter term observed transitions of the vegetation in northern Sweden will have substantial effects on the mountain ecosystems in the area. This area was excluded from the area of coverage included by Bhatt et al. (2010) but observed increases in shrub and tree cover are consistent with remote sensing studies of mountain birch forest densification reported by Tømmervik et al. (2004).

Further north, in high Arctic East Greenland (Jameson Land $70^{\circ} \mathrm{N}$ ), above-ground biomass in a moss fen ungrazed by geese more than doubled between 1982/1984 and 2008 and the temperature sum for June-July tripled (Madsen et al. 2011 [this issue]). During this period, the number of moulting geese had tripled. Despite consuming most of the graminoid production in available moss fens, and appearing to fill available habitat in 1982/1984, in 2008 overall plant species composition in a goose-grazed fen was unchanged but the frequency of graminoids had decreased and the area with dead vegetation and bare ground had increased. In a nearby moss fen ungrazed by geese, above ground plant biomass more than doubled. The net change of productivity in the area, i.e. the balance between grazed and ungrazed areas, is unknown but remote sensing shows a modest increase in the Normalized Difference Vegetation Index (NDVI) of the area (Bhatt et al. 2010). As in the example of treeline trees and shrubs outlined above, and inline with most warming experiments and models, climate warming appears to have lead to increased productivity. It is currently unknown, however if higher herbivory rates may have long-term negative consequences for the number of geese the habitat can sustain (Madsen et al. 2011 [this issue]).

On Herschel Island, also located at $70^{\circ} \mathrm{N}$ but on the western Arctic coast of the Yukon Territory, a BTF Project using examination of historic photographs, repeat vegetation surveys and monitoring of long-term plots provided evidence of considerable change in shrubiness during the twentieth century (Myers-Smith et al. 2011 [this issue]). In this study, canopy-forming willow (Salix richardsonii, $S$. glauca, and S. pulchra) patches increased in both size and height, and repeat photograph comparisons show that the former discrete patches of shrubs have now coalesced to nearly continuous cover in some areas, possibly as a result of establishment of new patches. A simple model indicated that the majority of willow patches for each of these species became established between 1910 and 1960, although some patches could have established as late as the 1980s. There was no evidence that expansion of willow patches is currently limited by herbivory, disease, or growing conditions. Shrub expansion in this area is consistent with the substantial increases in NDVI over the period 1982-2008 reported by Bhatt et al. (2010) and the general circum-polar increase in shrubiness (Sturm et al. 2001; Tape et al. 2006; Forbes et al. 2010; Hallinger et al. 2010; Rundqvist et al. 2011 [this issue]).

In contrast to these reports of considerable increases in productivity and area expansion of shrubs and graminoids that were predicted from warming experiments (Arft et al. 1999; Walker et al. 2006), results from Disko Island, Central West Greenland, at $69^{\circ} \mathrm{N}$ show only minor changes (Callaghan et al. 2011b [this issue]). Comparisons of photographs of a tall willow scrub (Salix glauca ssp. callicarpea), a rich herb slope, and fell-field community between 1967/1970 and 2009 show no signs of shrub height increase or expansion. However, re-sampling of species frequency and cover showed that some low shrubs (Betula nana and Empetrum nigrum) not recorded in 1967 had established at the fell-field site by 2009. During this period, temperature warming has only recently (since about 1984) become substantial (about $9^{\circ} \mathrm{C}$ maximum difference in mean annual temperature between 1984 and 2009). These modest changes nevertheless contrast with the lack of change over a 70 year period recorded on Svalbard at $78^{\circ} \mathrm{N}$ by Prach et al. (2010) even though both communities were superficially similar, and are open communities on exposed, gravely ground. Furthermore, the lack of obvious productivity changes on Disko Island is consistent with the lack of increase in NDVI measured between 1982 and 2008 (Bhatt et al. 2010).

\section{Changes in Plant Species Richness, Diversity and Community Structure}

Remote sensing proxies of changes in plant productivity to some extent integrate changes in productivity per se with changes in community structure and standing surface water (Goswami et al. 2011), each of which is difficult to isolate. In addition, there is a strong likelihood that there could have been changes in community composition and other characteristics that would not affect spectral indices such as NDVI, which could be used to indicate a change in productivity. Within BTF projects, detailed re-sampling of plant communities at several sites over multiple decades has provided evidence of both substantial change and lack of change in arctic plant communities and these are likely to greatly enhance capacities for validating space-borne remotely sensed products (sensu Bhatt et al. 2010). 
In the Yukon, Canada $\left(61^{\circ} \mathrm{N}\right)$, repeat measurements of alpine tundra communities surveyed in 1968 were made in 2010 (Danby et al. 2011 [this issue]). Plant community composition was resurveyed on the same four slopes using the same methods as the original study. Species richness and diversity increased significantly over the 42 years and ordination using non-metric multidimensional scaling indicated that community composition had also changed significantly. However, the direction and magnitude of change varied with aspect and dominant species were not replaced or eliminated but, instead, declined in relative importance. The period of study corresponds to a mean annual temperature increase of $2^{\circ} \mathrm{C}$, suggesting that climate warming has influenced these changes.

In a fell-field community on Disko Island, Central West Greenland, changes in species and communities were less pronounced (Callaghan et al. 2011b [this issue]). In contrast to the increase in species richness at the alpine site in the Yukon, there was a net species loss but in a herb-slope community, species losses were balanced by species gains. The type of species establishing and increasing in frequency and/or cover at the fell-field site, particularly prostrate dwarf shrubs, indicates a possible shift toward a heath, rather than a fell-field community. At the herb-slope site, those species that established or increased markedly in frequency and/or cover abundance indicate a change to drier conditions. This is confirmed both by the decrease in abundance of Alchemilla glomerulans and Epilobium hornemanii, and the drying of a nearby pond. The causes of these changes are unknown, although mean annual temperature range has been about $9^{\circ} \mathrm{C}$ since 1984 with the highest temperatures recently (Callaghan et al. 2011b [this issue]).

The observations from Disko Island generally parallel those from Tasiilaq, low arctic Southeast Greenland $\left(65^{\circ} \mathrm{N}\right)$ where change in the distinct Arctic vascular plant flora between around 1900 and 2007 was studied by comparing historic literature with field observations made in the late 1960s and in 2007 (Daniëls and de Molenaar. 2011 [this issue]). The similarity between the 1900 and 2007 floras was $90 \%$, as it was between the 1900 and 1968/1969 floras (Daniëls and de Molenaar 2011 [this issue]). Similarity between the 1968/1969 and 2007 floras was 98\%. Since 1900 , the percentage of widely distributed arctic species decreased distinctly, whereas that of the low-arctic species somewhat increased and boreal species increased very slightly. Vegetation monitoring of 110 sample plots revealed minor changes and showed that several thermophilous and xerophilous species increased between 1968/1969 and 2007, whereas some hygrophilous species decreased. In spite of climate warming, expansion of a nearby town, and increasing human impact including tourists, species composition of flora and vegetation on the whole was rather stable during the last 40 years and no invading species or introductions were recorded (Daniëls et al. 2011; Daniëls and de Molenaar 2011 [this issue]).

Other recently published BTF papers include Van Bogaert et al.'s (2010) study on treeline dynamics near Abisko in sub-arctic Sweden discussed above, and studies by Hudson and Henry (2009) and Hill and Henry (2011). The latter studies measured plant biomass in heath and wet sedge tundra communities at Alexandra Fiord, Ellesmere Island in the Canadian High Arctic and compared these with measurements made in the early 1980s. Significant increases in biomass were documented which correlate well with summer warming also documented for the study period. Interestingly, different plant groups responded differently within and between these the heath and wet sedge tundra communities. In another BTF plant community change study in the Canadian High Arctic on Baffin Island near the Barnes Ice Cap, plots that were re-measured in 2009 and compared with measurements made in 1964 show dramatic increases in plant cover, succession following deglaciation, a general drying of surface hydrology following loss of snowbeds as well as species range extensions (Bhatt et al. 2010; Walker et al. 2010). These ground-based BTF studies in the Canadian High Arctic strongly support Bhatt et al.'s (2010) report of large magnitude increases in NDVI documented for the region over the past three decades. Several other BTF vegetation and/or landscape and ecosystem studies are under final development and include additional sites in sub-arctic Sweden (Hedenås et al., in preparation), the Taymyr Peninsula (Matveyeva, in preparation), Beringia (Lin et al., in preparation), and multiple sites throughout the North American Arctic (Lara et al., in preparation, Villarreal et al. in preparation; see Fig. 1).

Mosses and lichens remain relatively poorly studied over multi-decadal time scales in the Arctic and have not been included in the majority of BTF studies in this Special Issue. Several BTF studies in preparation aim to improve this (e.g., Villarreal et al., in preparation). Some existing studies have shown that mosses and lichens in general are disadvantaged by climate warming as they tend to be outcompeted by responsive vascular plants and their litter (Lang et al. 2009; Van Wijk et al. 2004). In contrast, Jónsdóttir et al. (2005) found moss communities did not respond to experimental warming in Iceland compared to other experimental warming studies, and Hudson and Henry (2009) reported significant increases in bryophyte biomass between 1981 and 2008 on Ellesmere Island, which has warmed over the past few decades.

\section{Plant Communities in Transition}

Expansion of forest at treeline, increased shrubiness and graminoid abundance and increases in species richness 
denote substantial transitions in communities (Tape et al. 2006; Walker et al. 2006; Danby and Hik 2007). However, in some of the areas where such changes in plant community structure were not obvious (Tasiilaq and Disko Island, Greenland), small changes in plant species abundance nevertheless suggested the very early stages of a transition in one community to another. At Tasiilaq, new species recorded were predominantly low arctic in nature suggesting a development to a community of more benign environmental characteristics (Daniëls and de Molenaar 2011 [this issue]). Similarly, on Disko Island, the changes in species suggested a development from a fell-field to heath community and a drying of the herb-slope (Callaghan et al. 2011b [this issue]).

Such transitions from one community type to another were modeled for alpine tundra sites established during the International Biological Program on Niwot Ridge, Colorado, to establish hypotheses of future change trajectories for their BTF site that could be tested through sustained monitoring (Johnson et al. 2011 [this issue]). The authors use a probabilistic modeling approach that forecasts vegetation change using plant abundance data collected from marked plots established in 1971 and re-sampled in 1991 and 2001. Assuming future change can be inferred from past change, they extrapolate change for 100 years from 1971 and correlate trends for six plant communities (fell-field, dry meadow, moist meadow, wet meadow, snowbed, shrub tundra) with time series environmental data (1971-2001). Their observations showed possible two-way transitions between fell-field and dry meadow, which appeared to be decoupled from other community types. Moist meadow was found to be relatively stable over time and snowbed, wet meadow and shrub communities were found to be relatively dynamic. Also, the models suggest that once plots transitioned to shrub communities, they were unlikely to transition to another community. Projecting forward, the models predicted a marked decrease in the extent of snowbed vegetation (also observed in the sub-Arctic by Hedenås et al. 2011 [this issue] and Björk and Molau 2007) and a marked increase in the extent of shrub tundra by 2071 (as observed in many of the BTF, experimental and other studies reported above).

It has been argued that simple transitions from one current community to another might not occur (Melillo et al. 1990; Wookey 2008) because species respond to environmental change individualistically (Chapin and Shaver 1985) and new assemblages of species are likely to occur. However, in the BTF data sets, there is little evidence of changes in "conventional" community structure, although this has not been investigated quantitatively. Possible exceptions are the colonization of birch treeline forest by thermophilic aspen (Rundqvist et al. 2011 [this issue]; Van Bogaert et al. 2011) when replacement of birch by an evergreen tree species would be expected.

\section{CONCLUSIONS}

A limitation of the BTF approach is that it often provides "before and after" snapshots with little information on inter-annual variability, and no representation of extreme events (Bokhorst et al. 2009; Post et al. 2009). However, this Special Issue shows that there have been major losses in area and volume of glaciers in the Altai mountains over the past 60 years (in concert with the general trend for northern (SWIPA 2011) and global (IPCC 2007) glaciers), permafrost temperatures have increased in concert with those throughout the Arctic (SWIPA 2011), ice layers representing winter thaw processes have become more common in sub-arctic Sweden in the past 50 years, and ponds have decreased in area and physical and biological characteristics have changed in mid- and southeast Greenland and northern Alaska (Fig. 1). Plant community structure and species richness have varied from substantial change (most BTF vegetation studies) to almost no change. Where shrubs and trees were found, all BTF studies reported increases in woody plant cover and abundance in line with many other studies around the Arctic. Although attribution of the changes is difficult as many local factors can be involved, temperature increase appears to be an underlying feature in most studies reported in this issue.

The plant communities showed various degrees of resistance/resilience to change. The trends can be broadly ranked from maximum to minimum as: ponds $\geq$ forest and scrub $\geq$ snowbeds $>$ meadows $>$ heaths and fell-fields. Within communities, plant functional types responded differently over time: trees and shrubs $>$ graminoids $>$ herbs. Although these trends are similar to those found in ITEX experiments (Arft et al. 1999; Walker et al. 2006), the greater length of observation period and areal extent of observations (i.e., not plot-based) in the BTF studies confirms that the ITEX changes are persistent over time and that the relatively simple ITEX and pre-ITEX warming experiments appear to have been useful at forecasting future states of tundra plant communities.

The results for multi-decadal vegetation change presented here generally agree with the trends derived from satellite-based measurement of NDVI over the past three decades-1982 to 2008 (Bhatt et al. 2010). Also, the BTF data sets are uniquely able to assess dynamic vegetation model projections as the $40+$ year changes represent a significant time period within model projections for the next 100 years. BTF results validate many of the qualitative projections of current vegetation models applied to the Arctic, particularly the projections of increases in woody 
biomass and tree and shrub range extensions (e.g., Callaghan et al. 2005 (and references therein); Wolf et al. 2008; Wramneby et al. 2010). However, rates of change and extent of range margin shifts contrast between models and BTF observations. Forest has been predicted to displace between 11 and $50 \%$ of tundra between 2000 and 2100 . Already, however, one published BTF study has suggested that such current model projections could over-estimate treeline advance due to climate warming by about 2000 times (Van Bogaert et al. 2011). In contrast, BTF multidecadal observations of an increase in the density of woody vegetation in shrub and treeline areas suggest change has been dramatic (Myers-Smith et al. 2011; Rundqvist et al. 2011, both this issue) compared with model projections in general.

Since understanding the response of tundra systems to global change has global implications, and most tundra regions lack sustained environmental monitoring, there is an urgent need to maximize the capacity of using all approaches (experiments, remote sensing, modeling, repeat sampling of historical research sites) together (NRC 2006). The BTF results reported here have supported and provided improved capacities for validating these other approaches and exemplify the benefits of the BTF approach.

\section{LEGACY FROM BTF}

The BTF project was part of the IPY programme that sought legacy from its activities. BTF is built on the legacy of collaborations that were established primarily during the International Biological Program of the 1960s and 1970s and it provides further legacy for the future. The sites, studies, and data that have been recovered from many decades ago have now been preserved by the documentation in this volume and associated supplementary on-line material and many of the studies have archived data with respected data centers. Furthermore, knowledge has been transferred from older researchers, who established sites many decades ago, to young researchers and both generations appear in the authorship of almost every paper in this issue: BTF, therefore, represents an IPY legacy and has built capacity for future research in a rapidly changing environment.

Acknowledgments This study is part of the IPY project 512, "Back to the Future" (www.ipybtf.org). We thank all the contributors to this Special Issue and those that have published previously or are in the process of publishing - particularly the many graduate students who have contributed to and benefited from this project. The project would have been impossible without the formative studies of many researchers who established the IBP Tundra Biome project and other long-term studies exploited in the BTF study. The co-ordination of the project was financed by a grant from the Swedish Science Research Council (Vetenskapsrådet grant number 327-2007-833) to TVC and the US National Science Foundation (ANS-0732885, OPP-9906692) to CT. TVC also gratefully acknowledges support from the Swedish Research Council for Environment, Agricultural Sciences and Spatial Planning (Formas grants numbered 214-2008-188 and 214-2009389). The remaining co-authors acknowledge their national research councils for supporting their participation. Any opinions, findings, conclusions, or recommendations expressed in this material are those of the authors and do not necessarily reflect the views of the US-NSF.

\section{REFERENCES}

ACIA. 2005. Arctic climate impact assessment-scientific report, 1st ed. New York: Cambridge University Press.

Åkerman, H.J., and M. Johansson. 2008. Thawing permafrost and thicker active layers in sub-arctic Sweden. Permafrost and Periglacial Processes 19: 279-292.

Andrews, C., J. Dick, C. Jonasson, and T.V. Callaghan. 2011. Assessment of biological and environmental phenology at a landscape level from 30 years of fixed date repeat photography in Northern Sweden. Ambio. doi:10.1007/s13280-011-0167-z.

Arft, A.M., M.D. Walker, J. Gurevitch, J.M. Alatalo, M.S. Bret-Harte, M. Dale, M. Diemer, F. Gugerli, et al. 1999. Responses of tundra plants to experimental warming: Meta-analysis of the international tundra experiment. Ecological Monographs 69: 491-511.

Bhatt, U.S., D.A. Walker, M.K. Raynolds, J.C. Comiso, H.E. Epstein, G.S. Jia, R. Gens, J.E. Pinzon, et al. 2010. Circumpolar Arctic tundra vegetation change is linked to sea ice decline. Earth Interactions 14(8): 1-20.

Björk, R.G., and U. Molau. 2007. Ecology of Alpine snowbeds and the impact of global change. Arctic, Antarctic, and Alpine Research 39(1): 34-43.

Boelman, N.T., M. Stieglitz, K.L. Griffin, and G.R. Shaver. 2005. Inter-annual variability of NDVI in response to long-term warming and fertilization in wet sedge and tussock tundra. Oecologia 143(4): 588-597. doi:10.1007/s00442-005-0012-9.

Boelman, N.T., M. Stieglitz, H.M. Rueth, M. Sommerkorn, K.L. Griffin, G.R. Shaver, and J.A. Gamon. 2003. Response of NDVI, biomass, and ecosystem gas exchange to long-term warming and fertilization in wet sedge tundra. Oecologia 135(3): 414-421. doi:10.1007/s00442-003-1198-3.

Bokhorst, S., J.W. Bjerke, H. Tømmervik, T.V. Callaghan, and G.K. Phoenix. 2009. Winter warming events damage sub-Arctic vegetation: Consistent evidence from an experimental manipulation and a natural event. Journal of Ecology 97: 1408-1415.

Callaghan, T.V., L.O. Björn., Y. Chernov, F.S. Chapin, T.R. Christensen, B. Huntley, R. Ims, S. Jonasson, et al. 2005. Tundra and Polar Desert ecosystems. In ACIA. Arctic Climate Impact Assessment, 24-352. New York: Cambridge University Press.

Callaghan, T.V., C.E. Tweedie, and P.J. Webber. 2011a. Multidecadal changes in Tundra environments and ecosystems: The International Polar Year Back to the Future Project (IPY-BTF). Ambio. doi:10.1007/s13280-011-0162-4.

Callaghan, T.V., T.R. Cristensen, and E.J. Jantze. 2011b. Plant and vegetation dynamics on Disko Island, West Greenland: Snapshots separated by over 40 years. Ambio. doi:10.1007/s13280011-0169-x.

Callaghan, T.V., and C.E. Tweedie (eds.) 2011. Multi-decadal changes in Tundra environments and ecosystems-The International Polar Year Back to the Future Project. Ambio Special Issue 40(6).

Callaghan, T.V., F. Bergholm, T.R. Christensen, C. Jonasson, U. Kokfelt, and M. Johansson. 2010. A new climate era in the subArctic: Accelerating climate changes and multiple impacts. 
Geophysical Research Letters 37: L14705. doi:10.1029/2009 GL042064,2010.

Chapin, F.S., M. Berman, T.V. Callaghan, P. Convey, A.-S. Crépin, K. Danell, H. Ducklow, B. Forbes, et al. 2005a. Polar systems. In Ecosystems and human well-being, Vol. 1: Current state and trends, ed. R. Hassan, R. Scholes, and N. Ash, 717-746. Washington: Island Press.

Chapin, F.S., and G.R. Shaver. 1985. Individualistic growth response of tundra plant species to manipulation of light, temperature, and nutrients in a field experiment. Ecology 66: 564-576.

Chapin, F.S., G.R. Shaver, A.E. Giblin, K.J. Nadelhoffer, and J.A. Laundre. 1995. Responses of Arctic tundra to experimental and observed changes in climate. Ecology 76: 694-711.

Chapin, F.S., M. Sturm, M.C. Serreze, J.P. McFadden, J.R. Key, A.H. Lloyd, A.D. McGuire, T.S. Rupp, et al. 2005b. Role of landsurface changes in Arctic summer warming. Science 310: $657-660$.

Danby, R.K., S. Koh, D.S. Hik, and L.W. Price. 2011. Four decades of plant community change in the Alpine Tundra of Southwest Yukon, Canada. Ambio. doi:10.1007/s13280-011-0172-2.

Danby, R.K., and D.S. Hik. 2007. Variability, contingency, and rapid change in recent subarctic alpine treeline dynamics. Journal of Ecology 95: 352-363.

Daniëls, F.J.A., J.G. de Molenaar, M. Chytrý, and L. Tichý. 2011. Vegetation change in Southeast Greenland? Tasiilaq revisited after 40 years. Journal of Applied Vegetation Science 14: 230-241.

Daniëls, F.J.A., and J.G. de Molenaar. 2011. Flora and vegetation of Tasiilaq, Formerly Angmagssalik, Southeast Greenland-a comparison of data from between around 1900 and 2007. Ambio. doi:10.1007/s13280-011-0171-3.

Euskirchen, E.S., A.D. McGuire, F.S. Chapin, S. Yi, and C.D.C. Thompson. 2009. Changes in vegetation in northern Alaska under scenarios of climate change, 2003-2100: Implications for climate feedbacks. Ecological Applications 19: 1022-1043.

Forbes, B.C., M.M. Fauria, and P. Zetterberg. 2010. Russian Arctic warming and 'greening' are closely tracked by tundra shrub willows. Global Change Biology 16: 1542-1554.

Goswami, S., J.A. Gamon, and C.E. Tweedie. 2011. Surface hydrology of an arctic ecosystem: Multiscale analysis of a flooding and draining experiment using spectral reflectance. Journal of Geophysical Research 116: G00I07. doi:10.1029/ $2010 J G 001346$.

Hallinger, M., M. Manthey, and M. Wilmking. 2010. Establishing a missing link: Warm summers and winter snow cover promote shrub expansion into alpine tundra in Scandinavia. New Phytologist 186: 890-899.

Havström, M., T.V. Callaghan, and S. Jonasson. 1993. Differential growth responses of Cassiope tetragona, an arctic dwarf shrub, to environmental perturbations among three contrasting highand sub-arctic sites. Oikos 66: 389-402.

Hedenås, H., H. Olsson, C. Jonasson, J. Bergstedt, U. Dahlberg, and T.V. Callaghan. 2011. Changes in tree growth, biomass and vegetation over a thirteen-year period in the Swedish Sub-Arctic. Ambio. doi:10.1007/s13280-011-0173-1.

Henry, G.H.R., and U. Molau. 1997. Tundra plants and climatic change: The International Tundra Experiment (ITEX). Global Change Biology 3(1): 1-9.

Hill, G.B., and G.H.R. Henry. 2011. Responses of high Arctic wet sedge Tundra to climate warming since 1980. Global Change Biology 17: 276-287.

Hinzman, L.D., N.D. Bettez, W.R. Bolton, F.S. Chapin, N.B. Dyurgerov, C.L. Fastie, B. Griffith, R.D. Hollister, et al. 2005. Evidence and implications of recent climate change in northern Alaska and other arctic regions. Climatic Change 72: 251-298.
Hudson, J.M.G., and G.H.R. Henry. 2009. Increased plant biomass in a high Arctic heath community from 1981 to 2008. Ecology 90: 2657-2663.

IPCC. 2007. Climate change 2007: The physical science basiscontribution of working group I to the fourth assessment. Report of the intergovernmental panel on climate change. Cambridge: Cambridge University Press.

Johansson, C., V.A. Pohjola, C. Jonasson, and T.V. Callaghan. 2011. Multi-decadal changes in snow characteristics in sub-Arctic Sweden. Ambio. doi:10.1007/s13280-011-0164-2.

Johansson, M., J. Åkerman, F. Keuper, T.R. Christensen, H. Lantuit, and T.V. Callaghan. 2011. Past and present permafrost temperatures in the Abisko area: Redrilling of boreholes. Ambio. doi: 10.1007/s13280-011-0163-3.

Johansson, T., N. Malmer, P.M. Crill, T. Friborg, J.H. Akerman, M. Mastepanov, and T.R. Christensen. 2006. Decadal vegetation changes in a northern peatland, greenhouse gas fluxes and net radiative forcing. Global Change Biology 12: 2352-2369.

Johnson, D.R., D. Ebert-May, P.J. Webber, and C.E. Tweedie. 2011. Forecasting Alpine vegetation change using repeat sampling and a novel modeling approach. Ambio. doi:10.1007/s13280-0110175-z.

Jónsdóttir, I.S., B. Magnússon, J. Gudmundsson, Á. Elmarsdóttir, and H. Hjartarson. 2005. Variable sensitivity of plant communities in Iceland to experimental warming. Global Change Biology 11: 553-563. doi:10.1111/j.1365-2486.2005.00928.x.

Kaufman, D.S., D.P. Schneider, N.P. McKay, C.M. Ammann, R.S. Bradley, K.R. Briffa, G.H. Miller, B.L. Otto-Bliesner, et al. 2009. Recent warming reverses long-term Arctic cooling. Science 325: 1236-1239.

Kausrud, K.L., A. Mysterud, H. Steen, J.O. Vik, E. Østbye, B. Cazelles, E. Framstad, A.M. Eikeset, et al. 2008. Linking climate change to lemming cycles. Nature 456: 93-97.

Kohler, J., O. Brandt, M. Johansson, and T.V. Callaghan. 2006. A long Arctic snow depth record from Abisko, northern Sweden, 1913-2004. Polar Research 25(2): 91-113.

Krupnik, I., et al. 2011. Understanding Earth's polar challenges: International Polar Year 2007-2008. Summary Report by ICSU/ WMO Joint Committee for International Polar Year 2007-2008, University of the Arctic, Roveniemi. Edmonton: CCI Press.

Kullman, L. 2002. Rapid recent range-margin rise of tree and shrub species in the Swedish Scandes. Journal of Ecology 90: 68-77.

Kumpula, T., A. Pajunen, E. Kaarleja, B.C. Forbes, and F. Stammler. 2011. Land use and land cover change in Arctic Russia: Ecological and social implications of industrial development. Global Environmental Change. doi:10.1016/j.gloenvcha.2010. 12.010 .

Lang, S.I., J.H.C. Cornelissen, A. Hölzer, C.J.F. ter Braak, M. Ahrens, T.V. Callaghan, and R. Aerts. 2009. Determinants of cryptogam composition and diversity in Sphagnum-dominated peatlands: The importance of temporal, spatial and functional scales. Journal of Ecology 97: 299-310.

Lougheed, V.L., M.G. Butler, D.C. McEwen, and J.E. Hobbie. 2011. Changes in tundra pond limnology: Re-sampling Alaskan ponds after 40 years. Ambio. doi:10.1007/s13280-011-0165-1.

Madsen, J., C. Jaspers, M. Tamstorf, C.E. Mortensen, and F. Rigét. 2011. Long-term effects of grazing and global warming on the composition and carrying capacity of graminoid marshes for moulting geese in East Greenland. Ambio. doi:10.1007/s13280011-0170-4.

Melillo, J., T.V. Callaghan, F.I. Woodward, E. Salati, and S.K. Sinha. 1990. The effects on ecosystems. In Climate change, the IPCC Scientific Assessment, ed. J. Houghton, G.J. Jenkins, and J.J. Ephraums, 282-310. New York: Cambridge University Press.

Myers-Smith, I.H., D.S. Hik, C. Kennedy, D. Cooley, J.F. Johnstone, A.J. Kenney, and C.J. Krebs. 2011. Expansion of canopy- 
forming willows over the 20th century on Herschel Island, Yukon Territory, Canada. Ambio. doi:10.1007/s13280-0110168-y.

NRC. 2006. Toward an integrated arctic observing network. Washington, DC: The National Academy Press.

Olofsson, J., L. Oksanen, T.V. Callaghan, P.E. Hulme, T. Oksanen, and O. Suominen. 2009. Herbivores inhibit climate-driven shrub expansion on the tundra. Global Change Biology 15: 2681-2693.

Parsons, A.N., J.M. Welker, P.A. Wookey, M.C. Press, T.V. Callaghan, and J.A. Lee. 1994. Growth responses of four subarctic dwarf shrubs to simulated environmental change. Journal of Ecology 82: 307-318.

Post, E., M.C. Forchhammer, S. Bret-Harte, T.V. Callaghan, T.R. Christensen, B. Elberling, A.D. Fox, O. Gilg, et al. 2009. Ecological dynamics across the Arctic associated with recent climate change. Science 325: 1355-1358.

Prach, K., J. Kosnar, J. Klimesova, and M. Hais. 2010. High Arctic vegetation after 70 years: A repeated analysis from Svalbard. Polar Biology 33: 635-639.

Rundqvist,S., H. Hedenås, A. Sandström, U. Emanuelsson, H. Eriksson, C. Jonasson, and T.V. Callaghan. 2011. Tree and shrub expansion over the past 34 years at the tree-line near Abisko, Sweden. Ambio. doi:10.1007/s13280-011-0174-0.

Sandberg, G. 1963. Växtvärlden i Abisko nationalpark. In Natur $i$ Lappland, II ed, ed. K. Curry-Lindahl, 885-909. Uppsala: Bokförlaget Svensk Natur. (in Swedish).

Schuur, E.A.G., J. Bockheim, J.G. Canadell, E. Euskirchen, C.B. Field, S.V. Goryachkin, S. Hagemann, P. Kuhry, et al. 2008. Vulnerability of permafrost carbon to climate change: Implications for the global carbon cycle. BioScience 58: 701-714.

Shaver, G.R., T.V. Callaghan, C.E. Tweedie, and P.J. Webber. 2004. Flagship observatories for Arctic environmental research and monitoring. Woods Hole: Ecosystems Centre.

Smith, L.C., Y. Sheng, G.M. MacDonald, and L.D. Hinzman. 2005. Disappearing Arctic lakes. Science 308: 1429.

Smol, J.P., and M.S.V. Douglas. 2007. Crossing the final ecological threshold in high Arctic ponds. Proceedings of the National Academy of Sciences of the United States of America 104: 12395-12397.

Stow, D.A., A. Hope, D. McGuire, D. Verbyla, J. Gamon, F. Huemmrich, S. Houston, C. Racine, et al. 2004. Remote sensing of vegetation and land-cover change in Arctic Tundra ecosystems. Remote Sensing of Environment 89: 281-308.

Sturm, M., C.H. Racine, and K.D. Tape. 2001. Increasing shrub abundance in the Arctic. Nature 411: 546-547.

SWIPA. 2011. Snow, water, ice, permafrost in the Arctic. http://www. amap.no/swipa/.

Tape, K.D., M. Sturm, and C.H. Racine. 2006. The evidence for shrub expansion in Northern Alaska and the Pan-Arctic. Global Change Biology 12: 686-702.

Tømmervik, H., B. Johansen, I. Tombre, D. Thannheiser, K. Hogda, and E. Gaare. 2004. Vegetation changes in the Nordic mountain birch forest: The influence of grazing and climate change. Arctic, Antarctic, and Alpine Research 36: 323-332.

Van Bogaert, R., K. Haneca, J. Hoogesteger, C. Jonasson, M. De Dapper, and T.V. Callaghan. 2011. A century of tree line changes in sub-Arctic Sweden show local and regional variability and only a minor role of 20th century climate warming. Journal of Biogeography. doi:10.1111/j.1365-2699.2010.02453.x.
Van Bogaert, R., C. Jonasson, M. De Dapper, and T.V. Callaghan. 2009. Competitive interaction between aspen and birch moderated by invertebrate and vertebrate herbivores and climate warming. Plant Ecology \& Diversity 2: 221-232.

Van Bogaert, R., C. Jonasson, M. De Dapper, and T.V. Callaghan. 2010. Range expansion of thermophilic aspen (Populus tremula L.) in the Swedish Subarctic. Arctic, Antarctic, and Alpine Research 42: 362-375.

van Wijk, M.T., K.E. Clemmensen, G.R. Shaver, M. Williams, T.V. Callaghan, F.S. Chapin, J.H.C. Cornelissen, L. Gough, et al. 2004. Long-term ecosystem level experiments at Toolik Lake, Alaska, and at Abisko, Northern Sweden: Generalizations and differences in ecosystem and plant type responses to global change. Global Change Biology 10: 105-123.

Verbyla, D. 2008. The greening and browning of Alaska based on 1982-2003 satellite data. Global Ecology and Biogeography 17: $547-555$.

Walker, M.D., C.H. Wahren, R.D. Hollister, G.H.R. Henry, L.E. Ahlquist, J.M. Alatalo, M.S. Bret-Harte, M.P. Calef, et al. 2006. Plant community responses to experimental warming across the tundra biome. Proceedings of the National Academy of Sciences of the United States of America 103: 1342 -1346.

Walker, D.A., U.S. Bhatt, T.V. Callaghan, J.C. Comiso, H.E. Epstein, B.C. Forbes, M. Gill, W.A. Gould, et al. 2010. Vegetation. Bulletin of the American Meteorological Society 91: S115-S116.

Walter, K.M., M.E. Edwards, G. Grosse, S.A. Zimov, and F.S. Chapin. 2007. Thermokarst lakes as a source of atmospheric CH4 during the last deglaciation. Science 318: 633-636.

Wolf, A., T.V. Callaghan, and K. Larson. 2008. Future changes in vegetation and ecosystem function of the Barents Region. Climatic Change 87: 51-73.

Wookey, P.A. 2008. Experimental approaches to predicting the future of tundra plant communities. Plant Ecology and Diversity 1: 299-307.

Wramneby, A., B. Smith, and P. Samuelsson. 2010. Hot spots of vegetation-climate feedbacks under future greenhouse forcing in Europe. Journal of Geophysical Research 115: D21119. doi: 10.1029/2010JD014307.

\section{AUTHOR BIOGRAPHIES}

Terry V. Callaghan $(\bowtie)$ Terry Callaghan is a Distinguished Research Professor at the Royal Swedish Academy of Sciences and Professor of Arctic Ecology at Universities of Sheffield, UK and Lund, Sweden. He specializes in arctic ecology, and climate and UV-B radiation impacts on arctic ecosystems.

Address: Royal Swedish Academy of Sciences, Lilla Frescativägen 4 A, 11418 Stockholm, Sweden.

Address: Department of Animal and Plant Sciences, University of Sheffield, Western Bank, Sheffield S10 2TN, UK.

e-mail: terry_callaghan@btinternet.com

Craig E. Tweedie is an Assistant Professor in the Department of Biology and the Environmental Science and Engineering Program at the University of Texas at El Paso where he directs the Systems Ecology Laboratory (www.sel.utep.edu). His interests are global change science, cyberinfrastructure, and science education.

Address: Department of Biology, The University of Texas at El Paso, 500 West University Ave, El Paso, TX 79968-0519, USA.

e-mail: ctweedie@utep.edu 